\title{
Economic-financial evaluation and multicriteria analysis of innovative public transport guided systems: an application to "Linea della Musica" in Rome
}

\author{
S. Impastato, F. M. Rea \& S. Ricci \\ University of Rome "La Sapienza", Italy
}

\begin{abstract}
Trams and innovative public transport systems in historical city centres, are often not considered by public authorities, due to their strong visual impact, (e.g. in proximity of artistic-cultural places), and high project costs. The decision-makers guess that the high initial investment could not be compensated for in subsequent years. For this reason, it is very important to evaluate all the innovative solutions, not only economically, but considering all externalities, positive and negative, in a multi-criteria analysis taking into account public opinions and passengers' behaviours essential for assessing revenues, and also return of image. On this basis, the results may be impressive: the positive economic impact may be highlighted, and they can have a result better than traditional systems. The subject of the analysis is the innovative system "Tramwave" of Ansaldo STS that combines an investment cost imperceptibly higher than the traditional tram, and a zero visual impact due to the absence of the overhead line due to the uptake of electrical energy from the ground. This system, applied to "Linea della Musica", a planned tramway line in Rome, through a detailed financial balance of costs and revenues, shows a positive Net Present Value 3040 years after the initial investment. The current crisis, both culturally and economically, can cause two types of reactions: an indiscriminate cutting of essential public services, or a positive crackdown, that puts ideas in motion, awakens the pride of the common good, and realizes innovations for saving money. The proposed analysis will try to encourage the second reaction.
\end{abstract}

Keywords: tram, multicriteria, tramwave, costs, environment, Rome, externalities, innovation. 


\section{Introduction}

The "Linea della Musica", is a development project of public transport in North Rome zone, more precisely Parioli-Foro Italico-Prati districts, currently under study by the municipality of Rome, and is part of the three-year city plan provided by the decree "Salva Roma" including 7 new tramways sections all over the town. The Parioli district has an estimated potential usage of public transport up to 25,000 passengers per day, justifying the use of a tram system, with the highest peak near Euclide square; in fact actually there is no direct public transport line between Parioli street and Foro Italico district, and Parioli street itself is served by a low number of buses, only one working on Sundays, therefore a potential user is practically forced to use private vehicle with possible unregulated parking. With a tram line Parioli street would improve (Figures 1 and 2): today the roadway is $15 \mathrm{~m}$ wide allowing unregulated stopping that makes the traffic worse, two $5 \mathrm{~m}$ wide bands of regular parking on the roadside and wide sidewalks with a variable width between 2 and $9 \mathrm{~m}$; with the new project it would be possible to have $7 \mathrm{~m}$ double middle lane reserved for the tram only, or all public transport, $3.5 \mathrm{~m}$ double lane for private vehicles avoiding any unregulated parking, $4.8 \mathrm{~m}$ each side for regular parking and sidewalks $4.9 \mathrm{~m}$ wide.

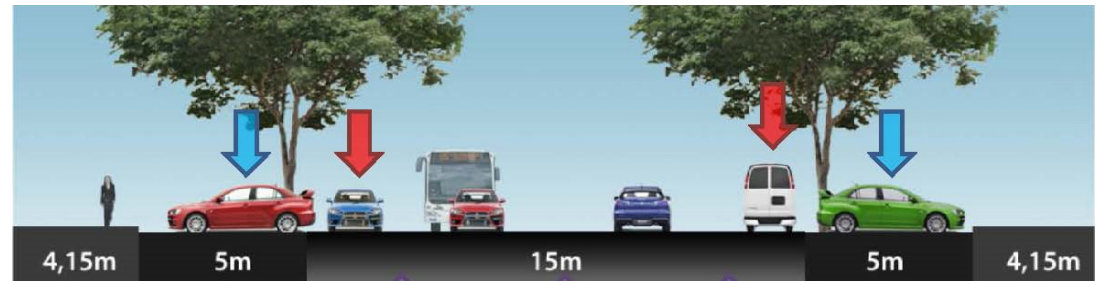

Figure 1: Present situation in Parioli Street.

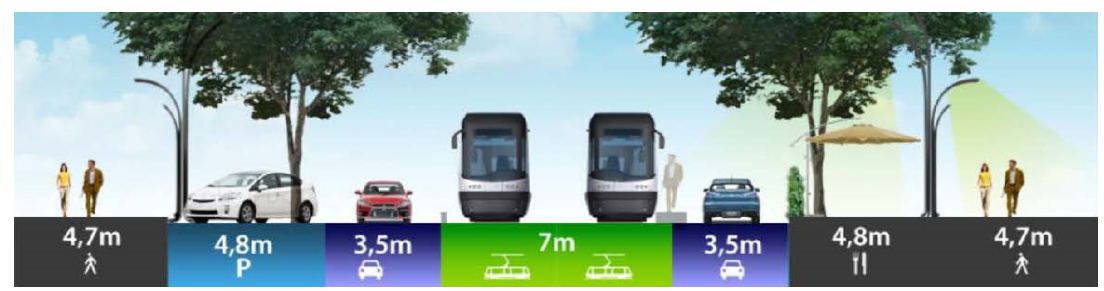

Figure 2: Future situation in Parioli Street.

There are 4 study cases, characterised by different transit systems: traditional bus, traditional trolleybus, traditional tram, and Tramwave [1-3]. For each case two scenarios are considered: the first has a commercial speed of $20 \mathrm{~km} / \mathrm{h}$, reachable with a protected lane only; the second a commercial speed of $15 \mathrm{~km} / \mathrm{h}$, similar to the present situation.

The characteristic data for each system are given in Table 1. 
The paper presents the results of the economic-financial analysis, including the definition of the various project costs, operating costs and revenues. A multicriteria analysis is also proposed, based on several criteria/sub-criteria with different weights, to consider the specificity of innovative transport systems considered.

Table 1: Characteristic data of analysed systems.

\begin{tabular}{|c|c|c|c|c|c|c|}
\hline System & $\begin{array}{c}\text { Line } \\
\text { ength } \\
(\mathrm{km})\end{array}$ & $\begin{array}{c}\text { Headway } \\
(\mathrm{min})\end{array}$ & $\begin{array}{c}\text { Commercial } \\
\text { speed } \\
(\mathrm{km} / \mathrm{h})\end{array}$ & $\begin{array}{c}\text { Travel time } \\
(\mathrm{min})\end{array}$ & $\begin{array}{c}\mathrm{N} . \\
\text { Vehicles }\end{array}$ & $\begin{array}{c}\mathrm{N} . \\
\text { Drivers }\end{array}$ \\
\hline Tramwave & 9.5 & 12 & 20 & 67 & 8 & 29 \\
\cline { 4 - 7 } $\begin{array}{c}\text { Traditional } \\
\text { Tram }\end{array}$ & 9.5 & 12 & 20 & 67 & 8 & 39 \\
\hline $\begin{array}{c}\text { Traditional } \\
\text { Trolleybus }\end{array}$ & 9.5 & 7 & 15 & 86 & 10 & 29 \\
\hline $\begin{array}{c}\text { Traditional } \\
\text { bus }\end{array}$ & 9.5 & 4 & 15 & 67 & 12 & 49 \\
\hline
\end{tabular}

\section{Economic and financial analysis}

The economic and financial analysis of the line is divided into two parts: the costs, divided into project and operating costs, and the revenues, split into passenger and advertising revenues. With the balance of costs and revenues it is possible to calculate the Net Present Value, which provides an indication of the economic sustainability of the project.

\subsection{Project costs}

The project cost or total investment is calculated taking into account the cost items as shown in eqn (1):

where:

$$
\mathrm{C}_{\mathrm{p}}=\mathrm{C}_{\mathrm{r}}+\mathrm{C}_{\mathrm{s}}+\mathrm{C}_{\mathrm{c}}+\mathrm{C}_{\mathrm{v}}
$$

$\mathrm{C}_{\mathrm{p}}=$ project cost,

$\mathrm{C}_{\mathrm{r}}=$ runway cost,

$\mathrm{C}_{\mathrm{s}}=$ stop cost,

$\mathrm{C}_{\mathrm{c}}=$ civil works cost,

$\mathrm{C}_{\mathrm{v}}=$ vehicles cost.

Project costs refer to the price book of the Lazio region, updated every year by the Regional Observatory on Public Works.

For a detailed analysis of the various cost items it is possible to refer to further studies by the same authors [4].

\subsection{Operating costs}

The annual operating costs take into account various factors given in eqn (2):

$$
\mathrm{C}_{\mathrm{o}}=\mathrm{C}_{\mathrm{d}}+\mathrm{C}_{\mathrm{f}}+\mathrm{C}_{\mathrm{m}}
$$


where:

$\mathrm{C}_{\mathrm{o}}=$ annual operating cost,

$\mathrm{C}_{\mathrm{d}}=$ drivers cost,

$\mathrm{C}_{\mathrm{f}}=$ fuel cost,

$\mathrm{C}_{\mathrm{m}}=$ maintenance cost.

\subsection{Revenues and net present value}

Revenues come from 2 sources: tickets and passes (passenger revenue) and advertising (advertising revenue).

Revenues of passengers have been calculated using a weighted average economic value for each passenger: $89.57 \%$ of tickets are BIT (Biglietto Integrato a Tempo $=€ 1.5$ ), with average amount of 2.7 trips, and $2.14 \%$ of tickets are BIG (Biglietto Integrato Giornaliero $=€ 6$ ), with average amount of 4.4 trips; $3.24 \%$ of tickets are ordinary monthly passes $=35 €$, with an average amount of 97.2 trips [5]. Through these data it is used eqn (3):

where:

$$
\mathrm{R}_{\mathrm{p}}=\mathrm{R}_{\mathrm{pu}} * \mathrm{~F}_{\mathrm{h}} *\left(\mathrm{H}_{\mathrm{p}}+\mathrm{H}_{\mathrm{m}}\right) * \mathrm{D}_{\mathrm{s}}
$$

$\mathrm{R}_{\mathrm{p}}=$ passenger revenue,

$\mathrm{R}_{\mathrm{pu}}=$ revenue per passenger,

$\mathrm{F}_{\mathrm{h}}=$ average passengers hourly flow,

$\mathrm{H}_{\mathrm{p}}+\mathrm{H}_{\mathrm{m}}=$ daily service hours,

$\mathrm{D}_{\mathrm{s}}=$ service days.

For "Linea della Musica", with the assumptions above, the annual passenger revenue can be estimated as $€ 4.5$ million.

About advertising revenues, considering an average value per passenger of $0.4 €[6]$, we use eqn (4):

$$
\mathrm{R}_{\mathrm{adv}}=\mathrm{R}_{\mathrm{advu}} * \mathrm{~F}_{\mathrm{h}} *\left(\mathrm{H}_{\mathrm{p}}+\mathrm{H}_{\mathrm{m}}\right) * \mathrm{D}_{\mathrm{s}}
$$

where:

$\mathrm{R}_{\mathrm{adv}}=$ advertising revenue,

$\mathrm{R}_{\mathrm{advu}}=$ advertising revenue per passenger,

$\mathrm{F}_{\mathrm{h}}=$ hourly average flow,

$\mathrm{H}_{\mathrm{p}}+\mathrm{H}_{\mathrm{m}}=$ daily service hours,

$\mathrm{D}_{\mathrm{s}}=$ service days,

The income is 3.3 million $€$.

On this basis the total revenues for each system are $€ 7.8$ million.

Another important aspect is the annual balance cost-revenues for each system. It is achieved by considering the revenues and expenses previously calculated with eqn (5):

where

$$
\mathrm{R}-\mathrm{C}=\mathrm{R}-\mathrm{C}_{0}-\mathrm{A}
$$

$\mathrm{R}-\mathrm{C}=$ balance revenues-cost, $\mathrm{R}=\mathrm{R}_{\mathrm{p}}+\mathrm{R}_{\mathrm{pub}}=$ total revenues, $\mathrm{C}_{\mathrm{o}}=$ annual operating costs, $\mathrm{A}=$ annual depreciation.

Finally, to make a realistic estimation of the economic balance of the line, it is calculated the net present value: the analysis was made at different time horizons: 15,30 and 40 years, which are the thresholds of technical life of the 
various parts of the infrastructure. A time of initial investment, without service is estimated, amounting to five years for Tramwave and the traditional tram, 3 years for trolleybus and 1 year for bus; the discount rate during the years of service is equal to $2 \%$.

During the years of initial investment the discount rate isn't applied and simply the depreciation is referred to as year 0 .

The eqn (6), used for the calculation of NPV for the service period, is:

$$
\mathrm{NPV}_{\mathrm{E}}=\left((\mathrm{R}-\mathrm{C}) /\left(1+\mathrm{R}_{\mathrm{d}}\right)^{\wedge} \mathrm{N}_{0}+\ldots+(\mathrm{R}-\mathrm{C}) /\left(1+\mathrm{R}_{\mathrm{d}}\right)^{\wedge} \mathrm{N}_{\mathrm{N}}\right) /\left(\mathrm{N}_{\mathrm{N}}-\mathrm{N}_{0}+1\right)
$$

where:

$\mathrm{NPV}_{\mathrm{E}}=$ net present value for service period,

$\mathrm{R}-\mathrm{C}=$ balance revenues-cost,

$\mathrm{R}_{\mathrm{d}}=$ discount rate,

$\mathrm{N}_{0}=\mathrm{n}$. years initial investment,

$\mathrm{N}_{\mathrm{N}}=\mathrm{n}$. years of operation.

The general formula to calculate total NPV is eqn (7):

where:

$$
\mathrm{NPV}=\mathrm{NPV}_{\mathrm{I}} * \mathrm{~N}_{0}+\mathrm{NPV}_{\mathrm{E}} * \mathrm{~N}_{\mathrm{N}}
$$

NPV=total NPV,

$\mathrm{NPV}_{\mathrm{I}}=\mathrm{A}=$ annual depreciation,

$\mathrm{NPV}_{\mathrm{E}}=\mathrm{NPV}$ per service year,

$\mathrm{N}_{0}=\mathrm{n}$. initial investment years $\mathrm{N}_{\mathrm{N}}=\mathrm{n}$. service years.

Table 2 summarizes the values of costs, revenues and the NPV for each case study and scenario.

Table 2: Value of costs, revenues and NPV (data in parentheses refer to

\begin{tabular}{|c|c|c|c|c|c|c|c|c|}
\hline 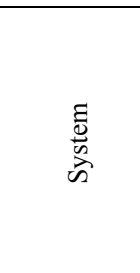 & 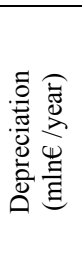 & 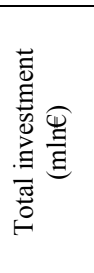 & 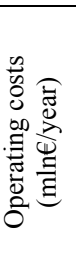 & 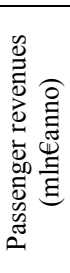 & 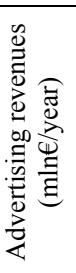 & 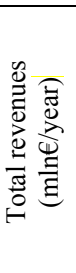 & 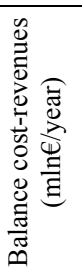 & 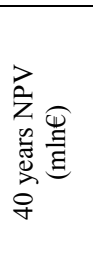 \\
\hline Tramwave & $\begin{array}{c}3 \\
(3.2)\end{array}$ & $\begin{array}{c}113.1 \\
(121.1)\end{array}$ & $\begin{array}{c}3 \\
(3.3)\end{array}$ & $\begin{array}{c}4.5 \\
(4.5)\end{array}$ & $\begin{array}{c}3.3 \\
(3.3)\end{array}$ & $\begin{array}{c}7.8 \\
(7.8)\end{array}$ & $\begin{array}{c}+1.8 \\
(+1.3)\end{array}$ & $\begin{array}{c}+27.8 \\
(+13.8)\end{array}$ \\
\hline Tram & $\begin{array}{c}2.9 \\
(3.1)\end{array}$ & $\begin{array}{c}108.3 \\
(116.3)\end{array}$ & $\begin{array}{c}3 \\
(3.3)\end{array}$ & $\begin{array}{c}4.5 \\
(4.5)\end{array}$ & $\begin{array}{c}3.3 \\
(3.3)\end{array}$ & $\begin{array}{c}7.8 \\
(7.8)\end{array}$ & $\begin{array}{c}+1.9 \\
(+1.4)\end{array}$ & $\begin{array}{c}+31.2 \\
(+17.2)\end{array}$ \\
\hline Trolleybus & $\begin{array}{c}2.5 \\
(2.6)\end{array}$ & $\begin{array}{c}44.7 \\
(47.1)\end{array}$ & $\begin{array}{c}4.7 \\
(5.3)\end{array}$ & $\begin{array}{c}4.5 \\
(4.5)\end{array}$ & $\begin{array}{c}3.3 \\
(3.3)\end{array}$ & $\begin{array}{c}7.8 \\
(7.8)\end{array}$ & $\begin{array}{l}+0.6 \\
(-0.1)\end{array}$ & $\begin{array}{l}+8.8 \\
(-9.7)\end{array}$ \\
\hline Bus & $\begin{array}{c}1.2 \\
(1.3)\end{array}$ & $\begin{array}{l}21.4 \\
(23)\end{array}$ & $\begin{array}{c}6.5 \\
(7.4)\end{array}$ & $\begin{array}{c}4.5 \\
(4.5)\end{array}$ & $\begin{array}{c}3.3 \\
(3.3)\end{array}$ & $\begin{array}{c}7.8 \\
(7.8)\end{array}$ & $\begin{array}{l}+0.1 \\
(-0.9)\end{array}$ & $\begin{array}{c}+2.2 \\
(-25.3)\end{array}$ \\
\hline
\end{tabular}
$\mathrm{V}=15 \mathrm{~km} / \mathrm{h})$. 
Assuming constant revenues, considering the different investment costs and operating costs, the cheapest system is traditional tram with a NPV (40 years) of $31.2 \mathrm{mln} €$, followed by Tramwave with $27.8 \mathrm{mln} €$, trolleybuses with $8.8 \mathrm{mln} €$ and finally the bus with $2.2 \mathrm{mln} €$. These costs decrease proportionally with the speed achieving negative values for trolleybuses and buses.

Fig. 3 shows the value of NPV 0-40 years.

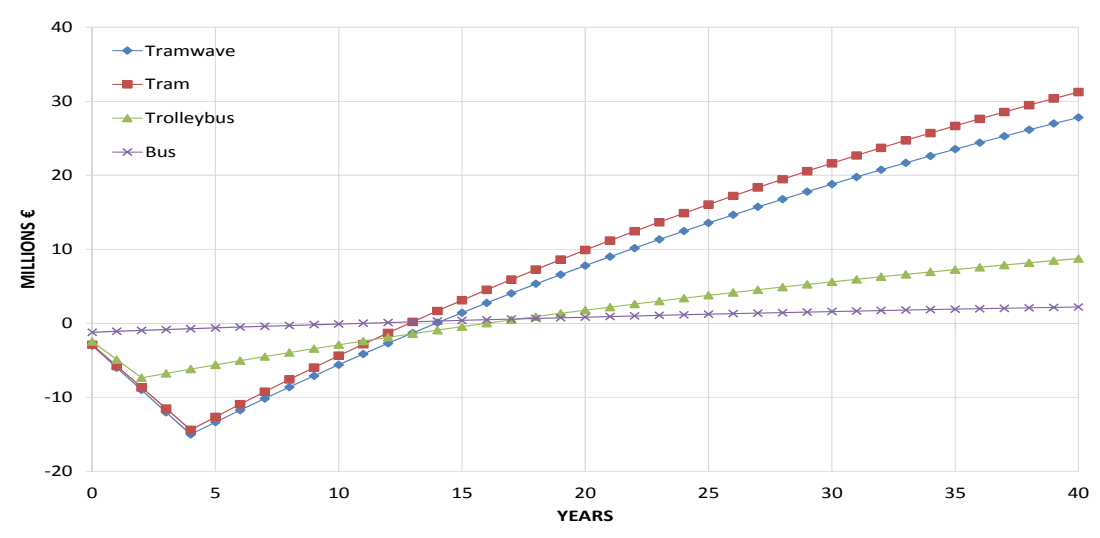

Figure 3: $\quad$ NPV (flow $=1400$ pass $/ \mathrm{h})$.

\subsection{Sensitivity analysis}

It is interesting to test the stability of the NPV when the initial assumptions change. The parameter that is certainly more significant and susceptible to oscillation is the average hourly flow, expected 1.400 passengers per hour according to the initial hypothesis. For every different scenario, taking into account the commercial speed of $20 \mathrm{~km} / \mathrm{h}$, it is calculated a progressive sum of annual average NPVs up to 40 years.

With $10 \%$ reduction in the flow, (1.200 passengers per hour) earnings are half for Tramwave, trams and buses, that after 40 years have an active respectively of 11 million€, 14.5 million€ and 1.4 million $€$, while there is a loss for trolleybuses, with a net loss of 8.6 million€.

In case of a $20 \%$ flow reduction (1.100 passengers per hour) the ranking of the economically best systems is reversed: the bus produces a gain of 5.9 million€, while the tram has a revenue of only 0.3 million€, Tramwave a loss of 0.8 million€ and the trolleybus a loss of 13 million€.

In case of a $30 \%$ reduction, (900 passengers per hour) the systems are all in loss, but the bus contains more the losses, 8.1 million€, while the tram loses 12.8 million€, Tramwave 16.2 million€, and trolleybus 29.8 million€.

In case of a $40 \%$ reduction (800 passengers per hour) losses increase while the ranking remains the same: the bus in 40 years loses 13.2 million€, tram 24.5 million€, Tramwave 27.9 million€, and trolleybus 35.9 million€. 
In the case of a 50\% reduction (700 passengers per hour), the trend of losses continues the bus loses 19.3 million€, tram 29 million€, the Tramwave 32.4 million€, and trolleybus has the record of 41.8 million€ lost in 40 years.

It is important to emphasize in this analysis that the trolleybus, which normally would be in an intermediate position of NPV between the tram and the bus, has a disadvantage for the investment costs proportionally greater than other systems for the line construction (this system needs overhead for all $9.5 \mathrm{~km}$ of track).

Another parameter affecting the balance revenues-cost, and then the NPV, is the technical life of the various items of the investment: the annual depreciation rate, weighted according to the life of the various components, is very susceptible to a small variation of the life duration to be taken into account.

In the case where the construction costs of the various systems vary proportionally, the changes are irrelevant for the cost comparison and, therefore, the order of economic convenience.

Figure 4 shows the trend of the NPV with a flow rate equal to $1100 \mathrm{pass} / \mathrm{h}$.

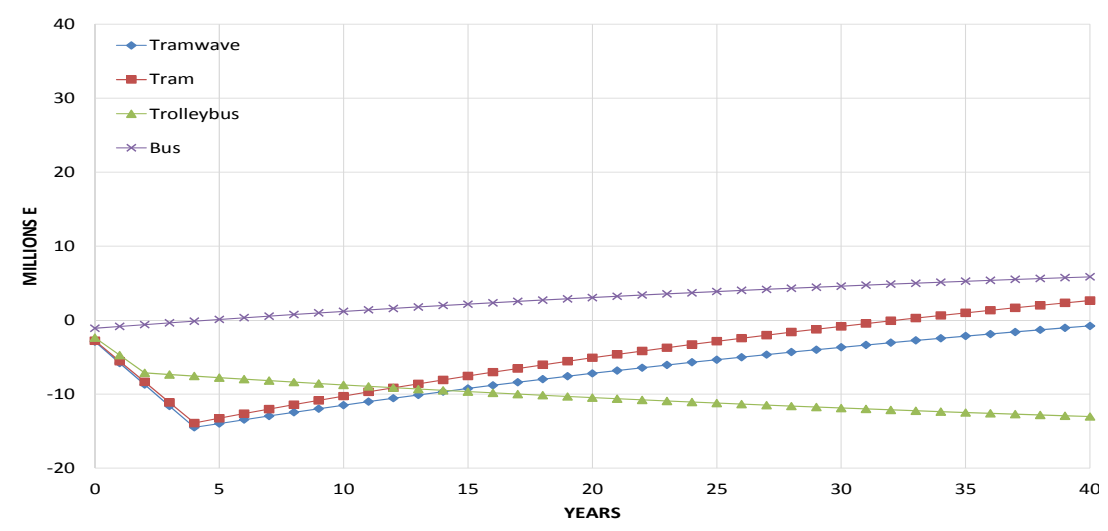

Figure 4: NPV (flow $=1100 \mathrm{pass} / \mathrm{h})$.

\section{Multicriteria analysis}

The economic and financial analysis, despite it is the most concrete part to be considered for the decision maker and for any investor, it does not consider all variables not strictly monetary but playing an important role in the assessment of the project: visual impact, noise and air pollution, vibration, service regularity, are just some of the many factors that have significant effects on the economic and political budget of local government and the community in general.

Therefore, it is very important to apply a proper multi-criteria analysis to the "Linea della Musica" project [7], including qualitative and quantitative criteria, weighted to give completeness and full meaning to the comparison between the alternatives. 
For all quantitative data (tables 3-4) was chosen to make a standardization by normalizing the values in a score between 1 and 6 . Criteria taken into account in the multicriteria analysis are relevance, feasibility, efficiency, and sustainability.

Inside the relevance there are the upgrade of the surrounding area, with a weight of 0.83 , and the similar experiences of using the systems, with a weight of 0.17 .

For area upgrade the bus has a score of 2, the trolleybus 4, 5 for the tram and for Tramwave 6, as it appears to be the most innovative system that leads to a general reorganization of the urban context benefiting users and the community.

For similar experiences, buses, trolleybuses and trams have a score of 6 , as they are strongly consolidated, unlike the Tramwave that, despite having been tested in Naples, was not experienced in regular operation, reason why it has a score of 2 .

About feasibility it have been considered operational status (implementation work) with a weight of 0.45 , the technical feasibility (ease in the implementation of infrastructural project) with a weight of 0.3 , the administrative feasibility (ease in obtaining permits, bureaucratic procedures etc.) with a weight of 0.25 . For operational status (related to state of design/construction), all the alternatives have a score of 1 , because they are all still hypothesis.

For technical feasibility, the simpler alternative considered to be technically implemented is the bus line, with a score of 6,5 for trolleybuses, and 4 for tram and Tramwave.

A similar ranking for the administrative feasibility: score of 6 for the bus, 5 for trolleybuses, and 4 for tram and Tramwave.

About efficiency there are parameters already discussed in the previous financial analysis: NPV, with a weight of 0.5 ; the target population, with a weight of 0.2 , and the regularity of the service, with a weight of 0.3 .

For the NPV we have values obtained in the financial analysis, normalized with eqn (8):

where

$$
\mathrm{V}_{\text {in }}=6 * \mathrm{~V}_{\mathrm{i}} / \mathrm{V}_{\max }
$$

$\mathrm{V}_{\text {in }}=$ normalized value,

$\mathrm{V}_{\mathrm{i}}=$ given value, and

$\mathrm{V}_{\max }=$ maximum value,

approximated to the nearest integer $\geq 1$. The bus has a score of 1,2 for trolleybus, 6 for tram and 5 for Tramwave; about target population all systems have a score of 6 , being the daily flow (25.900 passengers) an initial hypothesis.

The service regularity [8] of bus is $0.992,0.988$ for trolleybus, 0.991 for tram and Tramwave (hypothesis), to all systems the maximum score of 6 was assigned.

About sustainability are considered ability of financial recovery (number of years to reach a positive balance revenues-cost) with a weight of 0.38 , noise impact, air pollution, noise caused by vibration and the visual impact, all with a weight of 0.06, and economic robustness (annual average of the standard deviations for each value of the hourly flow), with a weight equal to 0.38 .

For the ability of financial recovery, the bus has an active in 11 years getting a score of 4 according to eqn (8), the trolleybus in 20 years getting a score of 1 , 
the tram in 14 and Tramwave in 15 getting both a score of 3; for the noise impact [9], it is evaluated for the bus an average of $65 \mathrm{~dB}$, for the trolleybus an average of $60 \mathrm{~dB}$, for tram and Tramwave an average noise of $46.4 \mathrm{~dB}$, and weights are calculated by eqn (9):

where

$$
\mathrm{V}_{\text {in }}=7-6 * \mathrm{~V}_{\mathrm{i}} / \mathrm{V}_{\max }
$$

$\mathrm{V}_{\text {in }}=$ normalized value,

$\mathrm{V}_{\mathrm{i}}=$ given value,

$\mathrm{V}_{\max }=$ maximum value.

Bus and trolleybus have a score of 1 , tram and Tramwave a score of 3 .

For air pollution [10], it is calculated an emission of bus of $0.069 \mathrm{~kg}$ of $\mathrm{CO}_{2}$ per passenger per $\mathrm{km}$, for trolleybuses, trams and Tramwave an emission of $0.042 \mathrm{~kg}$ of $\mathrm{CO}_{2}$ per passenger per $\mathrm{km}$, obtaining a score of 1 for the bus, and 3 for the remaining systems.

For noise caused by vibration, it is calculated a maximum level (Lmax) of $75 \mathrm{~dB}$ for buses and trolleybuses [11], with a score of 2, while for tram and Tramwave it is considered a maximum noise level (Lmax) of $82 \mathrm{~dB}$ [12], with a score of 1 .

For the visual impact it is considered the presence (or absence) of the overhead for the various systems, providing to bus and Tramwave a score of 6 , while trolleybuses and trams have a score of 1.

For the economic robustness, calculating an average reduction of annual hourly flow rate to $90 \%, 80 \%, 70 \%, 60 \%, 50 \%$ of the initial value, the bus obtains a value of 0.2 million€, the trolleybus 0.5 million€, the tram 1.01 million€ and the Tramwave a value of 1.03 million€, having the bus a score of 6 , the trolleybus 4 and 1 for trams and Tramwave.

Multiplying the scores of the sub-criteria for the relative weights is obtained a partial result, to be weighted again by the weights of the criteria: 0.35 for the relevance, for the feasibility $0.3,0.12$ for the efficiency and 0.23 for sustainability.

The analysis (table 5) shows the trolleybus and bus as alternatives with less success, (respectively 3.49 and 3.5 points), the tram is second with 3.78 points and Tramwave appears to be the preferable system with 3.85 points, changing the ranking previously taken into account with the financial analysis of NPV: with the externalities, even if expensive, innovative solutions are preferable to traditional systems.

\section{Conclusions}

This analysis was aimed to propose a methodology of analysis that could compare different transport systems with different technological solutions based on environmental, economic, technical, managerial and administrative aspects.

The result of the application of the methodology has shown the convenience of choosing a major investment to get not only a return of positive image for the city government and greater convenience for potential users of public transport, 


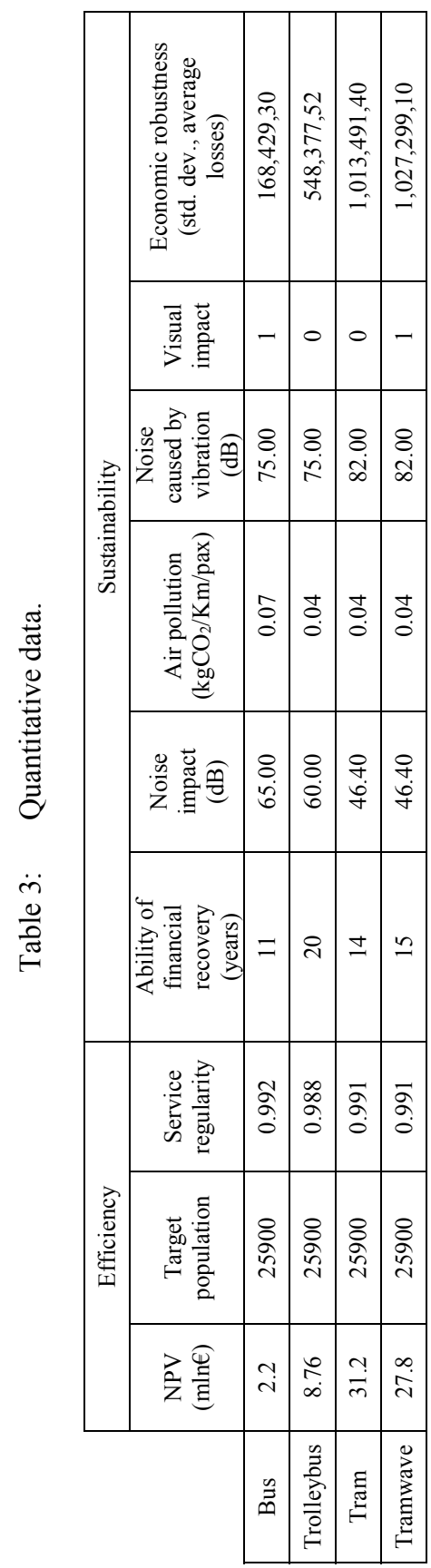

\begin{tabular}{|c|c|c|c|c|c|}
\hline \multirow{6}{*}{ 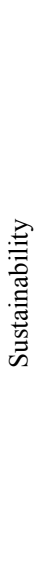 } & 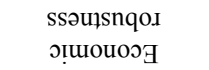 & 8. & $\begin{array}{l}8 \\
\dot{+}\end{array}$ & $\underset{8}{\&}$ & $\underset{.}{8}$ \\
\hline & Łoвdu! ן jens! & \&. & $\underset{-}{\stackrel{-}{2}}$ & 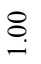 & $\begin{array}{l}8 \\
0 \\
0\end{array}$ \\
\hline & suo!̣e..q!^ & $\underset{i}{\stackrel{i}{i}}$ & $\underset{i}{\stackrel{8}{~}}$ & $\stackrel{8}{-}$ & $\stackrel{-}{-}$ \\
\hline & uo!̣nnIIod & $\stackrel{8}{.}$ & $\underset{\dot{r}}{\stackrel{.}{1}}$ & 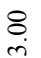 & $\underset{\dot{m}}{\stackrel{8}{c}}$ \\
\hline & ¡ərdu! əs!̣N & 8 & $\stackrel{8}{-}$ & 8 & $\underset{\dot{m}}{8}$ \\
\hline & 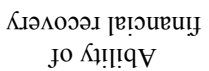 & $\underset{+}{\stackrel{+}{+}}$ & $\stackrel{8}{-}$ & $\underset{j}{\&}$ & 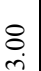 \\
\hline \multirow{3}{*}{ 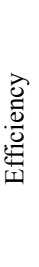 } & 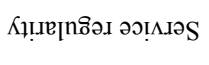 & \&. & $\underset{0}{8}$ & ه్ & $\underset{0}{8}$ \\
\hline & 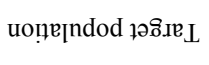 & \&. & $\underset{0}{8}$ & ه. & $\begin{array}{l}8 \\
0 \\
0\end{array}$ \\
\hline & $\Lambda \mathrm{dN}$ & $\stackrel{8}{-}$ & $\underset{i}{\stackrel{8}{i}}$ & $\underset{0}{8}$ & $\begin{array}{l}8 \\
\text { in }\end{array}$ \\
\hline \multirow{3}{*}{$\begin{array}{l}5 \\
0 \\
0 \\
0 \\
\\
\end{array}$} & 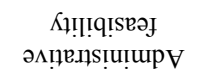 & \&. & $\begin{array}{l}8 \\
\dot{n}\end{array}$ & 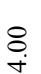 & $\begin{array}{l}\stackrel{8}{0} \\
\dot{+}\end{array}$ \\
\hline & 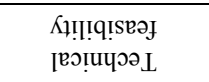 & \&. & $\begin{array}{l}8 \\
i\end{array}$ & $\underset{+}{\stackrel{\leftrightarrow}{+}}$ & $\underset{+}{\stackrel{+}{*}}$ \\
\hline & 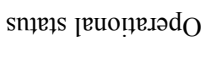 & $\stackrel{8}{.}$ & $\underset{-}{\stackrel{2}{2}}$ & $\underset{.}{8}$ & $\underset{-}{8}$ \\
\hline \multirow{2}{*}{ 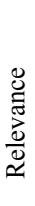 } & 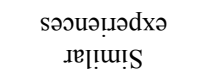 & 8 & $\underset{0}{8}$ & \&. & $\begin{array}{l}8 \\
i\end{array}$ \\
\hline & 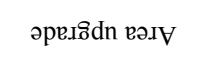 & $\underset{i}{8}$ & $\underset{+}{\stackrel{8}{+}}$ & $\begin{array}{l}8 \\
\text { in }\end{array}$ & $\begin{array}{l}8 \\
0 \\
0\end{array}$ \\
\hline & & $\stackrel{\mathscr{\nu}}{n}$ & 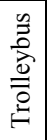 & 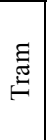 & 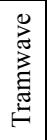 \\
\hline
\end{tabular}


Table 5: Ranking.

\begin{tabular}{|c|c|c|c|c|c|}
\cline { 2 - 6 } \multicolumn{1}{c|}{} & $\begin{array}{c}\text { Relevance } \\
(0.35)\end{array}$ & $\begin{array}{c}\text { Feasibility } \\
(0.3)\end{array}$ & $\begin{array}{c}\text { Efficiency } \\
(0.12)\end{array}$ & $\begin{array}{c}\text { Sustainability } \\
(0.23)\end{array}$ & TOT \\
\hline Bus & 2.68 & 3.75 & 3.5 & 4.4 & 3.50 \\
\hline Trolleybus & 4.34 & 3.2 & 4 & 2.32 & 3.49 \\
\hline Tram & 5.17 & 2.65 & 6 & 2 & 3.78 \\
\hline Tramwave & 5.32 & 2.65 & 5.5 & 2.3 & 3.85 \\
\hline
\end{tabular}

today almost forced to use private vehicles, but also a concrete economic profit. Although the choice of the traditional tram is slightly cheaper $(12 \%$ more profit in 40 years), the choice of the innovative system Tramwave, taken as an example in the analysis (but the concept is applicable also to all other innovative systems), appears to be the option with greater benefits: a gain in 40 years up to $€ 27.8$ million, and above all a perception of improvement in the quality of service by the users not comparable with conventional systems; in multicriteria analysis, where the financial impact is only one of the levels of analysis, the externalities make the difference. Sometime curiosity for innovations (in our case study, for example, the absence of catenary) and above all tangible elements such as improving the regularity and punctuality, are the elements that favor strongly Innovative Systems. It must be underlined, as it can be seen comparing the NPV at $15 \mathrm{~km} / \mathrm{h}$ and NPV at $20 \mathrm{~km} / \mathrm{h}$, that results are subjected to strong variations, due to the uncertainty of the data, such as the value of the commercial speed and also in consideration of the duration of the investment, for example the useful life of the infrastructure for the calculation of depreciation. Multicriteria analysis also increases the level of subjectivity for the many qualitative subcriteria, where the choice of assigning a particular score is not universal but is the result of an assessment of the designer and then inevitably subjected to uncertainties and interpretations; each weight, especially in models with numerous criteria, has limited influence on results.

If each transport line had a positive balance cost-revenues, (in Rome the network managed by ATAC in 2013 counts 331 surface lines), the whole community would have substantial benefits. This scenario is not impossible considering that it is reality in the world: Hong Kong Metro (MTR) with a profit of more than 800 million€ in 2013, a result that extended to 40 years can potentially provide 32 billion Euros to the Chinese city; Tokyo Metro with a positive in 2010 of almost 280 million€, profit that in 40 years would bring 11 billion Euros to the capital of Japan [13]. In Europe RATP of Paris ended the first half year of 2013 with a net profit of 190 million€ [14].

Public decision-makers have the task, more urgent than ever and that cannot be delayed, to take radical actions designed to permanently change the bad destiny, which appears to be irreversible, of public transport. 


\section{References}

[1] L. Rizzetto, Sicurezza e compatibilità geometrica della via dei tram-treno in ferrovia, Ingegneria Ferroviaria, 5 (Anno LXIV), pp. 457-476, 2009

[2] M.E. Lòpez-Lambas, C. Valdés, BHLS, bus, tram: thesis, antithesis, [2] synthesis, Ingegneria Ferroviaria, 6 (Anno LXVIII), pp. 569-585, 2013

[3] G. Maternini - S. Riccardi - M. Cadei, Transformation of a railway facility into a tramway. The case study of a tram-train system in the metropolitan area of Brescia, Ingegneria Ferroviaria, 3 (Anno LXIX), pp. 225-251, 2014

[4] F.M. Rea, Sistemi innovativi per il trasporto urbano: un'applicazione per la "Linea della Musica" di Roma, Bachelor degree thesis - Sapienza Università di Roma, 2014

[5] A. Spinosa, Bus, filobus oppure rotaie?, iBinari+Cityrailways, $\mathrm{p} 44,2011$

[6] A. Spinosa, Bus, filobus oppure rotaie?, iBinari+Cityrailways, p. 45, 2011

[7] Formez, L'analisi a supporto delle decisioni, 2004

[8] Carta della mobilità 2012, Atm SpA, 2012

[9] Jason C. Ross, Michael A. Staiano, A comparison of green and conventional diesel bus noise levels, 2007 TramStore21 Report, Noise \& Vibrations, 2012

[10] Co2nnect, http://www.co2nnect.org

[11] Office of Planning and Environment Federal Transit Administration, Transit noise and vibration impact assessment, 2006

[12] TramStore21 Report, Noise \& Vibrations, 2012

[13] Mazlan, http://hubpages.com/hub/Top-4-MRT-Systems-in-Asia

[14] Ferpress, http://www.ferpress.it/?p=115060 